\title{
Animal Ethics and Animal Use in Laparoscopic Surgery
} Hayvan Etiği ve Laparoskopik Cerrahide Hayvan Kullanımı

\author{
Kahraman Ülker', Ürfettin Hüseyinoğlu² \\ ${ }^{1}$ Kafkeas University School of Medicine, Department of Obstetrics And Gynecology, Kars, Turkey, ${ }^{2}$ Kafkeas University School of Medicine, Department \\ of Anesthesia and Reanimation, Kars, Turkey
}

\begin{abstract}
AIM: We aimed to analyze the trends in experimental animal use and the ethical approval rates of the publications dealing with the improvement of the laparoscopic surgery during the last two decades.

METHODS: The study was performed by using the available online medical search engines. We searched the PubMed for the proportion of biomedical publications used animals between 1990 and 2010. Journals with English Abstracts, organized in chronological order from the earliest to the oldest. The search was narrowed to include only the key word "laparoscopy". We gathered 3023 studies performed on animals. We included the studies with objectives to innovate, improve or modify a laparoscopic technique, instrument or device. The publications in which the objective of the study was not to improve the laparoscopic approach were excluded. The remaining 82 studies were analyzed for the data including the year of the study, animal species, and the number of the animals at the initial phase and at the end of the studies, and the ethical approval status.
\end{abstract}

RESULTS: The study included 21 studies in 1990-2000 decade and 61 studies in 2000-2010 decade groups. A total of 2132 animals, 496 in 1990-2000 decade and 1636 in 2000-2010 decade, were used in the studies. Most widely used animals were pigs followed by rats, rabbits and dogs.

The numbers of animals per study and animal death rates were not significantly different between two decades ( $p>0.05$ ). Although, the ethical committee approval rate increased, the increase was not sufficient enough to create a significant difference ( $p>0.05)$.

CONCLUSION: Researchers mostly perform experiments on pigs to achieve improvements in laparoscopic surgery. Although, there was a tendency towards to a small increase in ethical approval rate and a small decrease in unnecessary animal death rate in the last decade, we still have a long way to go as the ethical approval rate fluctuates around $70 \%$ in animal studies.

Key words: animal experimentation, animal experimental use; ethics; laparoscopic surgery; laparoscopic surgical procedure; minimally invasive surgical procedures

Kabraman Ülker, Kafkas Üniversitesi T⿰力 Fakïltesi Kadin Hastallklar ve Doğum Anabilim Dal, Kars, Türkiye, Tel. 047472251026 Email. kahramanulker@, botmail.com Gelis Taribi: 13.10.2012 • Kabul Taribi: 22.10.2012
ÖZET

AMAÇ: Son yirmi yıldaki deneysel hayvan kullanımı eğilimlerini ve laparoskopik cerrahiyi ilerletmek için yapılmıș yayınlardaki etik bașvuru oranlarını incelemeyi amaçladık.

YÖNTEM: Çalıșma ulașılabilen on-line arama motorları kullanılarak yapıldı. 1990 ve 2010 yılları arasında hayvanları kullanan biomedikal çalıșma oranlarını belirlemek için PubMed'i inceledeik. Ingilizce özeti olan dergiler en eskiden en yeniye doğru kronolojik olarak sıralandılar. Arama yalnızca "laparoscopy" anahtar kelimesini içerecek biçimde daraltıldı. Hayvanlar üzerinde yapılan 3023 çalıșma elde ettik. Bir laparoskopi tekniği, cihazı ya da aleti bulmak, geliștirmek ya da değiștirmeyi amaç edinen çalıșmaları içerdik. Laparoskopik yaklașımı geliștirmeyi amaç edinmeyen çalıșmalar çıkarıldılar. Kalan 82 çalıșma; çalıșma yılı, hayvan türü, çalıșmaların bașında ve sonundaki hayvan sayısı ve etik bașvuru durumu açısından incelendiler.

BULGULAR: Çalıșmada 1990-2000 yılları arasındaki 10 yılda yayınIanan 21 ve 2000-2010 yılları arasındaki 10 yılda yayınlanan 61 çalıșma yer aldı. Toplam 2132 hayvandan 496's ilk 10 yıldaki ve 1636'sı ikinci 10 yıldaki çalıșmalarda kullanılmıșlardı. En çok kullanılan hayvan olan domuzları sırasıyla ratlar, tavșanlar ve köpekler takip ediyordu.

İki on yıllık süre içerisinde çalıșma bașına kullanılan hayvan sayısı ve hayvan ölüm oranları belirgin olarak farklı değillerdi $(p>0,05)$. Etik bașvuru oranları artsa da, bu artıș belirgin fark olușturmak için yeterli değildi $(p>0,05)$.

SONUÇ: Laparoskopik cerrahide gelișme sağlamak için araștırmacılar çoğunlukla domuzlar üzerinde deneyler yapmaktadırlar. Son iki 10 yıllık sürede, etik bașvuru oranında küçük bir artıș ve gereksiz hayvan ölüm oranında küçük bir azalma olsa da, hayvan çalıșmalarında etik bașvuru oranı \%70'lerde olduğu için hala kat edilmesi gereken çok yol vardır.

Anahtar kelimeler: hayvan deneyleri, deneysel hayvan kullanımı; etik; laparoskopik cerrrahi; laparoskopik cerrahi ișlemler; minimal invazif cerrahi ișlemler

\section{Introduction}

The wide use of animals in health researches has introduced the thoughts of the rights and ethics of the experimental animals which mainly concerned about the unnecessary suffering and death of the experimental animals. The principles of Humane Experimental 
Technique was published by Russell and Burch in 1959 and consisted of the 3Rs statement: replacement (if applicable use of alternative methods instead of animals), reduction (use reduced numbers of animals to achieve scientific objectives) and refinement (use methods to minimize animal suffering). ${ }^{1}$

Council for International Organizations of Medical Science (CIOMS) adopted the 3Rs in 1985 and revised in 1993 and $2002^{2}$, thereafter the 3Rs statement was universally accepted and specific guides were formed $^{3}$. In United Kingdom the ethical review process of scientific procedures was incorporated into Animal Act 1986. ${ }^{4}$ Following the passage of the act, almost every scientific journal began to request for the statement of ethical approval in the articles consisting comprising the use of animals in their methodology. However, many papers have been published without the using of the statement.

Laparoscopic surgery has gained a tremendous worldwide popularity since 80 s due to its advantages over laparotomy. The advantages are shorter hospitalization, better cosmetics, faster recovery and earlier return to normal activity, less postoperative adhesion formation and the suitability for the outpatient settings in most cases ${ }^{5}$.

Laparoscopic surgery is the gold standard for many surgical procedures. Common surgical procedures like appendectomy, cholecystectomy, cystectomy, and tubal ligation are performed in many centers. Almost any gynaecologic surgery including the hysterectomies, urogynaecologic and oncologic procedures have been performed laparoscopically in some advanced centers ${ }^{6}$. In order to achieve this high surgical standards, many animals were used in surgical experiments and training programs. However, experimental studies performed on animals are still needed.

Currently some mammalian species are the most widely preferred animals for experimental studies. The animals with the highest frequencies to be involved in the experiments are the rats, mice, rabbits and fish. The pigs, guinea pigs, hamsters and the monkeys have moderate frequencies to be involved in experiments.

In the last few decades ethical committees used strict limitations for the use of various species in experimental animal studies. In some cases, researchers could hardly find the suitable species for their experiments.

In this study, we aimed to analyze the trends in experimental animal use and the ethical approval rates of the published data dealing with the improvement of the laparoscopic surgery during the last two decades.

\section{Methods}

The study was performed by using the available online medical search engines including Google, Google academic and mainly pub-med between September and December 2010.

\section{Internet search/review}

The internet search was on key words and phrases such as "animal study, experimental animals, ethics, laparoscopy", which yielded 42.400 results but most of them were not specific to experimental animal use, ethical approval or laparoscopic surgery. In order to identify the rate and quality of animal use to improve the laparoscopic practices in human beings we included only the medical journals. We searched the Pub Med (http://www.nlm.nih.gov) for the proportion of biomedical publications used animals. The search included from 1990 to 2010. Journals with English Abstracts, organized in chronological order from the earliest to the oldest. The search was narrowed to include only the key word "laparoscopy". We gathered 3023 studies performed on animals.

\section{Publication selection}

Of the 3023 publications, 324 free full text papers were selected for a detailed analysis in order not to miss the data that was not presented in the abstracts. The selected full text papers were analyzed for the objectives of the studies. We included the studies with objectives to innovate, improve or modify a laparoscopic technique, instrument or device. The publications in which the objective of the study was not to improve the laparoscopic approach were excluded. The remaining 82 studies were analyzed for the data including the year of the study, animal species, and the number of the animals at the initial phase and at the end of the studies, and the ethical approval status.

The decade 1990-2000 included time between January $1^{\text {st }}$ of 1990 and December $31^{\text {st }}$ of 1999 and similarly the decade 2000-2010 included time between January $1^{\text {st }}$ of 2000 and December $31^{\text {st }}$ of 2010 . Ethical approval status was classified as "approved" or "not approved". In case where the authors did not mention the ethical approval status, it is considered as "not approved". The declaration of the adherence to the certain laws and the experimental study standards was not considered as ethical approval. 


\section{Statistical analysis}

Statistical analyses were performed using SPSS version 16.0 software (SPSS Inc, Chicago, IL). Independent samples Student's t test was used to compare the normally distributed data between the decades 1990 2000 and 2000-2010. Non-normally distributed data was compared by using Mann Whitney U test. Chisquare test was used to analyze the intra-group variables. Correlation analysis among the parameters was performed by using the Pearson's test. A p value $<0.05$ was considered statistically significant.

\section{Results}

The study included 21 studies in 1990-2000 decade and 61 studies in 2000-2010 decade groups. A total

Table 1. Animal preferences in studies with objectives to innovate, improve or modify a laparoscopic technique, instrument or device.

\begin{tabular}{lcc}
\hline Animals & Study number $(\mathrm{N}=82)$ & Percentage $(\%)$ \\
\hline Pigs & 38 & 46,3 \\
Rats & 18 & 22 \\
Rabbits & 8 & 9,7 \\
Dogs & 6 & 7,3 \\
Mice & 4 & 4,8 \\
Baboons & 3 & 3,6 \\
Cows & 2 & 2,4 \\
Hamsters & 1 & 1,3 \\
Goats & 1 & 1,3 \\
Sheep & 1 & 1,3 \\
\hline Chi-square test demonstrated that the preferred animals were significantly different $(p<0.05)$ \\
\hline
\end{tabular}

of 2132 animals, 496 in 1990-2000 decade and 1636 in 2000-2010 decade, were used in the studies. Animal preference in studies with objectives to improve laparoscopic approach was summarized in Table 1. Most widely used animals were pigs followed by rats, rabbits and dogs.

Although the saved animal counts were higher in 20002010 group, in order to prevent a misunderstanding the reader should know that the initial animal counts and animal death rates were also higher in the group (Table 2). In addition the differences were not significant $(\mathrm{p}>0.05)$. The ethical committee approval rate increased through this period (Figure 1). However, the difference between the two decades, 1990-2000 and 2000-2010, was not significant ( $p>0.05$ ).

Table 2. The comparison of 1990 s and 2000s. The initial and saved animal numbers, and animal death and ethical approval rates were presented as mean \pm standard deviation and percent, respectively.

\begin{tabular}{lccc}
\hline & $1990-2000$ & $2000-2010$ & $p$ value \\
\hline $\begin{array}{l}\text { Mean animal count } \\
\text { per study }\end{array}$ & $23.62 \pm 22.35$ & $26.82 \pm 36.52$ & ${ }^{*} 0.996$ \\
$\begin{array}{l}\text { Saved animal count } \\
\text { per study }\end{array}$ & $3.05 \pm 6.01$ & $7.02 \pm 19.87$ & ${ }^{*} 0.872$ \\
$\begin{array}{l}\text { Animal death } \\
\text { rate (\%) }\end{array}$ & 67 & 75 & ${ }^{*} 0.520$ \\
$\begin{array}{l}\text { Ethical approval } \\
\text { rate (\%) }\end{array}$ & 57 & 69 & ${ }^{* *} 0.335$ \\
$\begin{array}{l}{ }^{*} \text { Mann Whitney Test, **ndependent samples t test } \\
\end{array}$
\end{tabular}

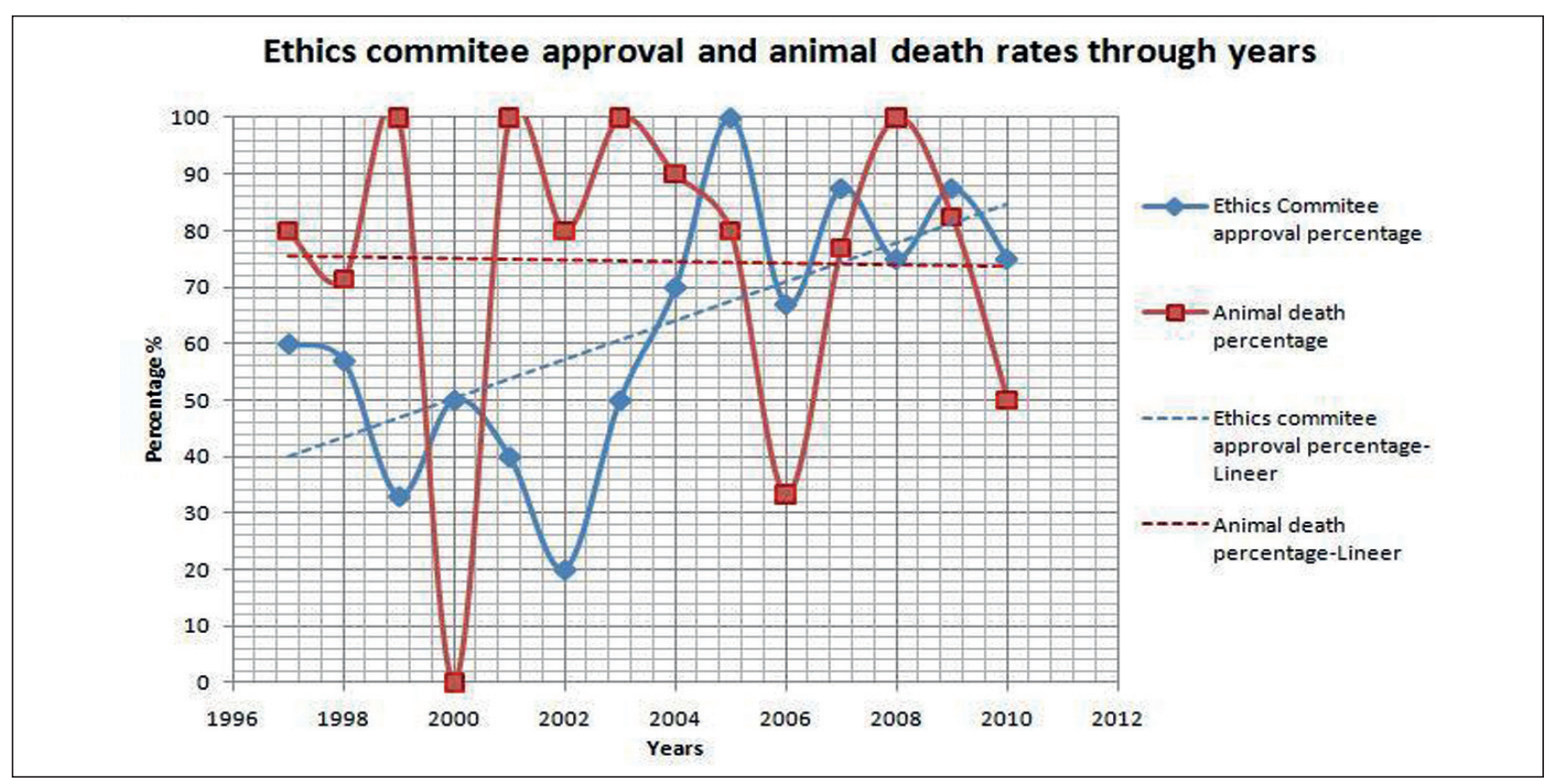


The correlation analysis showed that the animal counts at the beginning of the experiment positively correlated with the saved animal counts $(p<0.05)$, however they did not correlate with the year of publication, decade, and the rates of animal death or ethical approval $(\mathrm{p}>0.05)$. The ethical approval rate positively correlated with the year of the publication $(p<0.05)$, but not with the decade of the publication, initial and saved animal counts and animal death rates $(\mathrm{p}>0.05)$.

\section{Discussion}

\section{Principal findings}

The ethical approval rate for the animal studies with an objective aiming to improve the laparoscopic approach increased from 1990 to 2010; however the increase rate was not sufficient enough to create a significant difference through the two decades. The counts of animal use, deaths and the rate of animal death did not change between decades. In addition the pigs are the most widely preferred animals for laparoscopy related studies.

\section{Strengths and limitations}

To our knowledge the present study is the first dealing a specific area of animal ethics, improvement of the laparoscopic surgery approaches for the health and welfare of the humans. Depending on the ethnicity, tradition, religion and the behaviour of the people living in a certain country ethical regulations may differ. The use of a certain animal in a certain study protocol may be banned in some countries depending on the aforementioned facts. However, the scientific truth and the objectiveness of the results should depend on the evidences. In this point of view, our study may cause a re-evaluation of the attitudes of some ethical committees.

The study revealed data by using the online search engines, mostly PubMed. However, most of the studies dealing with animals are not indexed in PubMed. In addition, most of the core journals indexed in PubMed, for financial profit based reasons, are not freely accessible. Moreover, there is not an existing mechanism to control the truthfulness of the declerations and most journals rely on the declaration. We also do not know that the ethical approval ensures the strict ethical behavioural adherence.

\section{Comparison with the previous studies and the guides}

International Committee of Medical Editor Journals (ICMJE) states that "When reporting experiments on animals, authors should indicate whether the institutional and national guide for the care and use of laboratory animals was followed" ". Although almost all medical journals declare that they strictly adhere to the ICMJE's statement, however, our study demonstrates the ethical approval rate was not significantly higher in 2000s than the rate of 1990s and reached only to $69 \%$.

The animal ethics targeting the protection of animal abuse was first instituted in the United Kingdom during 1980s. In Turkey there are two laws passed in 2003 and 2004, which regulate the welfare of the animals $^{8,9}$. Beginning from 1980s various countries passed laws to a legal basis for the animal protection $^{10}$. However, our study shows that the ethical approval rates did not change significantly during the last two decades.

The number of journals stating that authors should indicate whether the institutional and national guidelines for the care and use of laboratory animals were followed is increasing. However, the proportion of journals without a clear policy was still more than $50 \%$ in $2009^{11}$, which may caused the absence of declaration of ethical approval and compliance to the guidelines. In our study the ethical approval rate was increased $12 \%$ from 1990 s to 2000 s, however the change was not significant ( $\mathrm{p}>0.05)$.

Over the period between 1995 and 2009 the total number of procedures involving animals followed an increasing trend. However, the proportion of the procedures involving genetically modified animals increased in time and exceeded the number of procedures involving normal animals in $2009^{12}$. Genetically modified animals are produced to be a more predictive model for human diseases and the results of the researches involving genetically modified animals potentially are more reliable for many authors, reviewers and editors. However, despite the fact, the rates of ethical approval and the declaration of the compliance to the guidelines are not at the desirable levels.

For research under the Animals Scientific Procedures Act 1986, cats, dogs and horses can only be used if no other animals are suitable ${ }^{13}$. In addition in these specific circumstances 3 Rs and animal welfare should 
be provided. Although, there were alternatives (i.e. pigs), our study showed that in $7.3 \%$ of the studies the dogs were used in laparoscopic surgery.

Animals have been used in scientific researches since 400 B. $C^{14}$ and because animal research has contributed too many medical advances such as the invention and production of the vaccines, antibiotics and anaesthetics, they will also be used in the future ${ }^{15,16}$. Although our study demonstrated that ethical approval rate in animal studies increases slightly, the rate is around $70 \%$ and is not significantly higher than the rate 10 years ago. In addition we need further studies to have detailed data about the animal experiments and ethical sanctions.

\section{Conclusion}

Researchers mostly perform experiments on pigs to achieve improvements in laparoscopic surgery. Although, there was a tendency towards to a small increase in ethical approval rate and a small decrease in unnecessary animal death rate in the last decade, we still have a long way to go as the ethical approval rate fluctuates around $70 \%$ in animal studies.

\section{References}

1. William Russell and Rex Burch: The Principles of Humane Experimental Technique, Great Britain 1959; cited by Flecknell P: Replacement, reduction and refinement. Altex 2002; 19 (2): 73-8.

2. Ulman YI, Ulus İH, Özpınar A, Genç SV: Preliminary Notes for Ethical Conduct of Animal Experimentation with Special Reference to Studies in Turkey. Kafkas Univ Vet Fak Derg 2011; 17(6): 1051-6.

3. Olfert ED, Cross BM, McWilliam AA. Canadian Council on Animal Care, 1993. Guide to the care and use of experimental animals. http://www.ccac.ca/Documents/ Standards/Guidelines/Experimental_Animals_Vol1.pdf. Last access 12-Oct-2012.

4. The 1986 Act. Guidance on the operations of the Animals (Scientific Procedures) Act 1986. http://www.archive.officialdocuments.co.uk/document/hoc/321/321-01.htm\#gen41. Last access 07-Oct-2012.

5. Goldberg JM. Indications and contraindications for laparoscopy. In: Falcone T, Goldberg JM. Basic, Advanced and Robotic Laparoscopic Surgery. Saunders; 2010: Chap 2.

6. Schlaerth AC, Abu-Rustum NR. Role of minimally invasive surgery in gynaecologic cancers. Oncologist 2006; 11(8):895901. [Medline].
7. International Committee of Medical Journal Editors (ICMJE). Uniform Requirements for Manuscripts Submitted to Biomedical Journals: Ethical Considerations in the Conduct and Reporting of Research: Protection of human subjects and animals in research. http://www.icmje.org/ ethical_6protection.html. Last access 08-Oct-2012.

8. Resmi Gazete: Ev Hayvanlarının Korunmasına Dair Avrupa Sözleşmesinin Onaylanmasının Uygun Bulunduğu Hakkında Kanun, No. 4934, Date: 15.07.2003: http://www.tbmm.gov. tr/kanunlar/k4934.html, Last access 10-Sept-2012.

9. Resmi Gazete: Hayvanları Koruma Kanunu, No. 5199, Date: 24.06.2004, http://www.tbmm.gov.tr/kanunlar/k5199.html, Last access 10-Sept-2012.

10. Rezende A, Peluzio M, Sabarense C. Animal experimentation: ethics and Brazilian legislation. Rev Nutr Campinas 2008; 21:237-42.

11. Osborne NJ, Payne D, Newman ML. Journal editorial policies, animal welfare and 3Rs. Am J Bioeth 2009; 8(12):55-9.

12. Understanding animal research. Animal research in United Kingdom: the numbers in perspective. http://www. understandinganimalresearch.org.uk/assets/document/ AC13C7F5-B48C-B33C-668872770F913A2A/2011\%20 Briefing $\% 20$ on $\% 20$ numbers $\% 20$ of $\% 20$ animals 2 .pdf Last access 12-Oct-2012.

13. National center for replacement, refinement and reduction of animals in research. Responsibility in the use of animals in bioscience research: Expectations of the major research council and charitable funding bodies. http://www.nc3rs.org. uk/page.asp?id=871 Last access 12-Oct-2012.

14. Altuğ T. Hayvan Deneyleri Etiği. http://uvt.ulakbim.gov.tr/ tip/sempozyum7/altug.pdf Last access 09-Sept-2012.

15. Understanding animal research. How do we do research with animals? Research process. http://www. understandinganimalresearch.org.uk/how/research-process Last access 11-Oct-2012.

16. Understanding animal research. Where do medicines come from? http:/ / www.understandinganimalresearch.org.uk/how/ research-process. Last access 12-Oct-2012. 